\title{
Gonadotrophin-binding sites in the ovary of aged rats
}

\author{
R. W. Steger, J. J. Peluso, H. Huang*, E. S. E. Hafez and J. Meites* \\ Reproductive Physiology Laboratories, C. S. Mott Center for Human Growth and Development, \\ Wayne State University School of Medicine, Detroit, Michigan 48201, and \\ * Department of Physiology, Michigan State University, East Lansing, Michigan 48823, U.S.A.
}

Several recent reports have indicated that non-cyclic old female rats exhibit significant changes in hypothalamic, pituitary and ovarian functions (Clemens, Amenomori, Jenkins \& Meites, 1969; Shaar, Euker, Riegle \& Meites, 1975; Huang \& Meites, 1975). Old rats showed fewer compensatory ovulations in response to hemicastration than young rats (Peppler, 1972). A decrease in ovarian compensatory hypertrophy in response to unilateral ovariectomy was observed in old rats by Labhsetwar (1970), but not by Howland \& Preiss (1975). Shaar et al. (1975) reported that bilateral ovariectomy resulted in a significantly smaller rise in serum LH in old females than in young mature female rats. The structure and function of CL from old rats also appear to be abnormal and may contribute to the decline in reproductive capacity (Mandl, 1959; Jones 1970). In the present experiment, therefore, the ability of the aged rat ovary to bind ${ }^{125}$ I-labelled LH and FSH and to localize the areas of $\Delta^{5}-3 \beta$-hydroxysteroid dehydrogenase ( $3 \beta$-HSD) activity was assessed.

\section{Methods}

Long-Evans rats obtained from Blue Spruce Farms (Altamont, New York) were housed in controlled environmental conditions $\left(24 \pm 1^{\circ} \mathrm{C}, 14 \mathrm{hr}\right.$ light $\left./ 24 \mathrm{hr}\right)$. Food and water were always available. Vaginal smears were taken daily between 16.00 and 17.00 hours to establish the reproductive state. Retired breeders, aged 18-20 months, were killed if they showed constant vaginal cornification (constant oestrus) or 10-30 days of predominantly leucocytic smears (pseudopregnant-like). Virgin females, 10-12 weeks old, and killed on the day of oestrus or 4 days after the induction of pseudopregnancy by cervical stimulation, were used as controls. One ovary from each animal was fixed in Bouin's fluid while the remaining ovary was placed in an embedding medium, OCT compound (Ames Co., Elkhart, Indiana), frozen in a solid $\mathrm{CO}_{2}$-ethanol bath and stored at $-20^{\circ} \mathrm{C}$. There were four animals in each group.

The hormone preparations and the method for localization of ${ }^{125}$ I-labelled gonadotrophinbinding sites were as described previously (Peluso, Steger \& Hafez, 1976). Frozen sections were cut, incubated with ${ }^{125}$ I-labelled gonadotrophins, washed and then prepared for autoradiography. For examination of $3 \beta$-HSD activity, the sections were extracted for $15 \mathrm{~min}$ in cold acetone $\left(4^{\circ} \mathrm{C}\right)$, rinsed in 2 changes of $0.2 \mathrm{M}$-tris buffer $\left(4^{\circ} \mathrm{C}, \mathrm{pH} 7.4\right)$ and incubated for $60 \mathrm{~min}$ at $37^{\circ} \mathrm{C}$ in a solution containing $20 \mathrm{ml} \mathrm{0.2} \mathrm{M}$-tris buffer (pH 7.4), $10 \mathrm{mg}$ Nitro-Blue Tetrazolium, $20 \mathrm{mg}$ NAD and $2 \mathrm{mg}$ pregnenolone (Blaha \& Leavitt, 1970). The sections were fixed in buffered formalin (pH 7.0), rinsed in distilled water and mounted in glycerol-gelatin. Control sections were processed in an incubation solution without pregnenolone to ensure that all endogenous substrate was removed by the acetone.

Sections from the Bouin-fixed tissue were stained with haematoxylin and eosin or Mallory's trichrome.

\section{Results and discussion}

The young oestrous and pseudopregnant control rats had ovaries with the normal complement of developing follicles and $C L$. The aged constant-oestrous rats had ovaries with large fluid-filled cystic follicles which usually had a thin and uneven granulosa layer and ranged in diameter from 1 to $3 \mathrm{~mm}$. CL were never found in these rats, although medium antral and small preantral follicles were often present. The aged pseudopregnant rats had numerous large CL as well as medium antral and small preantral follicles. 
The CL of the aged pseudopregnant rats were histologically different from those of young animals; there were fewer well-formed luteal cells per high-power field, as evidenced by the lack of round nuclei and the presence of vacuolated cells, but the CL bound LH as did the CL of the young control animals (PI. 1, Figs 1 and 2). FSH did not bind appreciably to the CL of either group. The CL of the aged rats generally showed more $3 \beta-H S D$ activity than the CL of either group of young rats (Pl. 1, Figs 3 and 4).

Medium-sized antral follicles bound LH and FSH regardless of age: the thecal cells bound only LH while both LH and FSH bound to the membrana granulosa cells (Pl. 2, Figs 5, 6 and 7). In the young and old rats, the granulosa cells of some small antral follicles bound FSH but not LH. The activity of $3 \beta$-HSD was localized over the thecal and granulosa cells in all groups (Pl. 2, Fig. 8).

The cystic follicles in the old constant-oestrous rats had few granulosa cells. Those present showed minimal LH and FSH binding activity but still retained some $3 \beta-H S D$ activity. The thecal

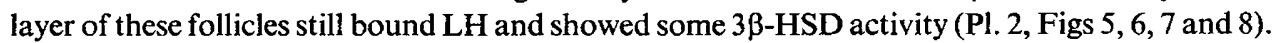

The interstitial tissue from all animals bound LH and showed good $3 \beta-$ HSD activity (Pl. 2, Figs

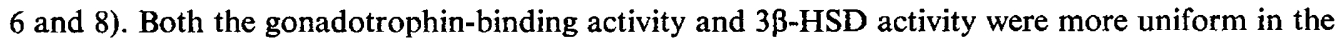
young animals than in the aged animals. Tissue adjacent to the interstitial areas showed no gonadotrophin binding or enzyme activity and was often fibrous in nature.

The binding of ${ }^{125} \mathrm{I}$-labelled LH or FSH to ovarian structures was inhibited by incubating the sections with a large excess of the respective unlabelled gonadotrophin. Control sections for the $3 \beta$-HSD localization which were incubated without substrate showed no formazan deposits.

The aged rat ovary still retains the capacity to bind gonadotrophins in a manner qualitatively similar to that of ovaries from young cyclic rats. These findings are in accord with the observations that the aged ovary can ovulate and/or maintain regular oestrous cycles with the proper hormonal stimulus (Aschheim, 1965; Peng \& Huang, 1972; Clemens et al., 1969). Both groups of aged rats had antral follicles which appeared histologically intact and were capable of binding both FSH and LH. In the growing follicle, first FSH and then LH binding sites develop as the follicle matures (Peluso et al., 1976). The fact that the aged ovary has small antral follicles binding only FSH and mediumsized antral follicles binding both $\mathrm{LH}$ and FSH suggests that follicles are continuing to develop, presumably in response to endogenous gonadotrophins (Ryle, 1972). Follicles which do not ovulate gradually lose LH and FSH binding sites as atresia progresses (J. J. Peluso, unpublished data). Like atretic follicles, cystic follicles have limited gonadotrophin-binding activity and old constantoestrous rats with cystic follicles do not readily ovulate (Huang \& Meites, 1975).

The CL of aged pseudopregnant rats show changes in luteal cell morphology that may represent functional alterations, and are similar to those reported for the aged mouse CL (Harman \& Talbert, 1970). The CL of young and old rats, however, appeared to bind LH equally, suggesting that the decline of CL function is not due to lack of $\mathrm{LH}$ binding sites. There was $3 \beta$-HSD activity in the CL from old and young rats indicating the presence of some steroidogenic potential. However, Leathem \& Murono (1975) showed that $3 \beta$-HSD activity was altered in regard to substrate specificity in ageing animals, suggesting a change in CL function.

This research was supported by Ford Foundation Grant No. 710-0287A and National Institute of Aging Grant No. AG-00416.

\section{References}

Aschнeim, P. (1965) La réactivation de l'ovaires des rattes seniles en oestrus permanent on moyen d'hormones gonadotropes on de la mise a l'obscurité. C. r. hebd. Séanc. Acad. Sci., Paris 260, 56275630.

Blaha, G.C. \& Leavit, W.W. (1970) The distribution of ovarian $\triangle^{5}$-3 $\beta$-hydroxysteroid dehydrogenase activity in the golden hamster during the estrous cycle, pregnancy and lactation. Biol. Reprod. 3, 362-368.
Clemens, J.A., Amenomori, Y., Jenkins, T. \& Meites, J. (1969) Effects of hypothalamic stimulation, hormones and drugs on ovarian function in old female rats. Proc. Soc. exp. Biol. Med. 132, 561-563.

HaRman, S.M. \& TALBerT, G.B. (1970) The effect of maternal age on ovulation, corpora lutea of pregnancy and implantation failure in mice. J. Reprod. Fert. 23, 33-39.

Howland, B.E. \& Preiss, C. (1975) Effect of aging on basal levels of serum gonadotrophins, ovarian 
PLATE 1
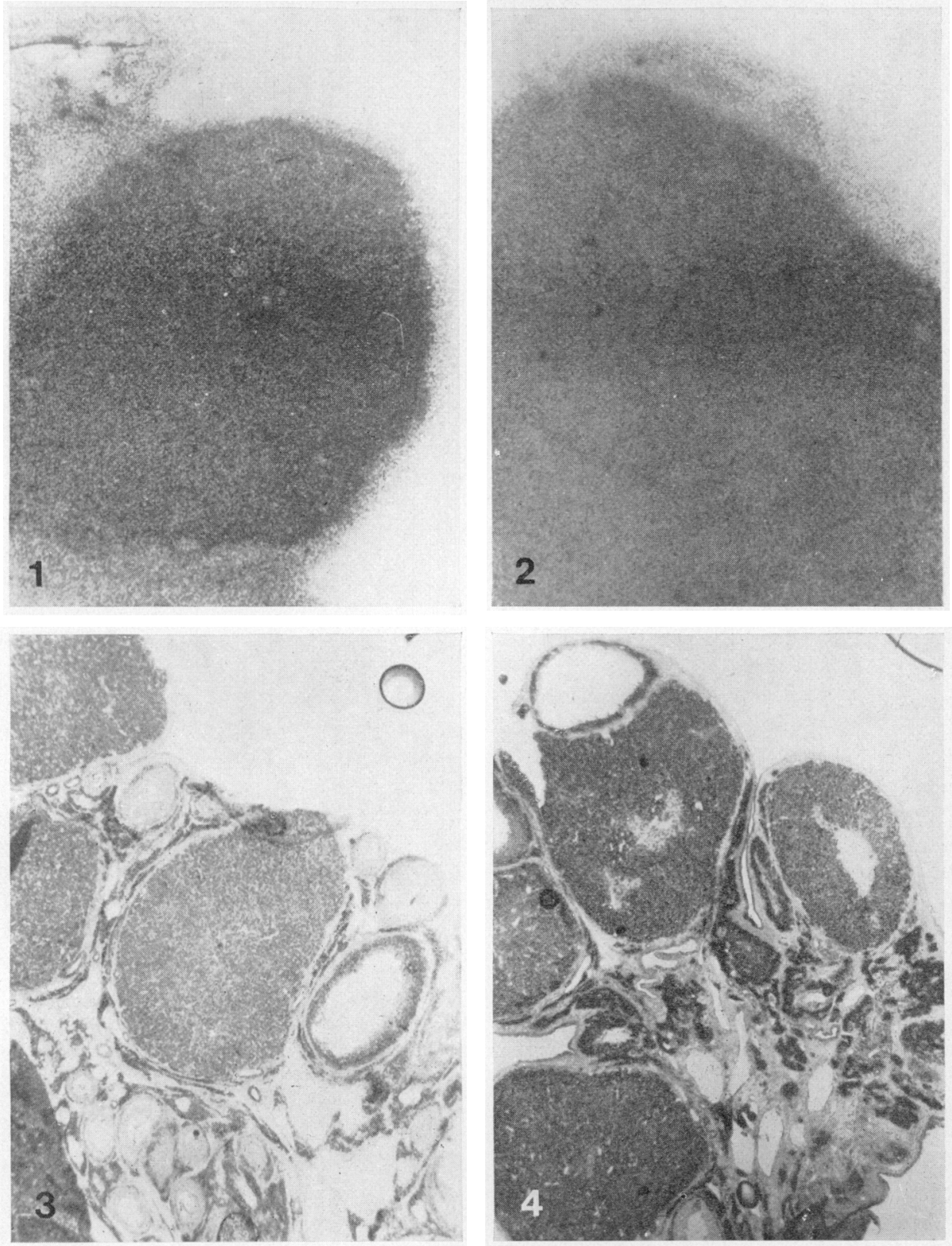

Figs $\mathrm{I}$ and 2. LH binding by the $\mathrm{C} L$ of young pseudopregnant (Fig. 1) and old pscudopregnant-like rats (Fig. 2) showing uniform distribution of the hormone over the $\mathrm{CL} . \times 175$.

Figs 3 and 4. Activity of $3 \beta$-hydroxysteroid dehydrogerase in the $C$ L of young pseudopregnant (Fig. 3 ) and old pseudopregnant-like rats (Fig. 4). Note the 3/3-HSD activity localized over the interstitium in both sections. $\times 70$. 
PLATE 2
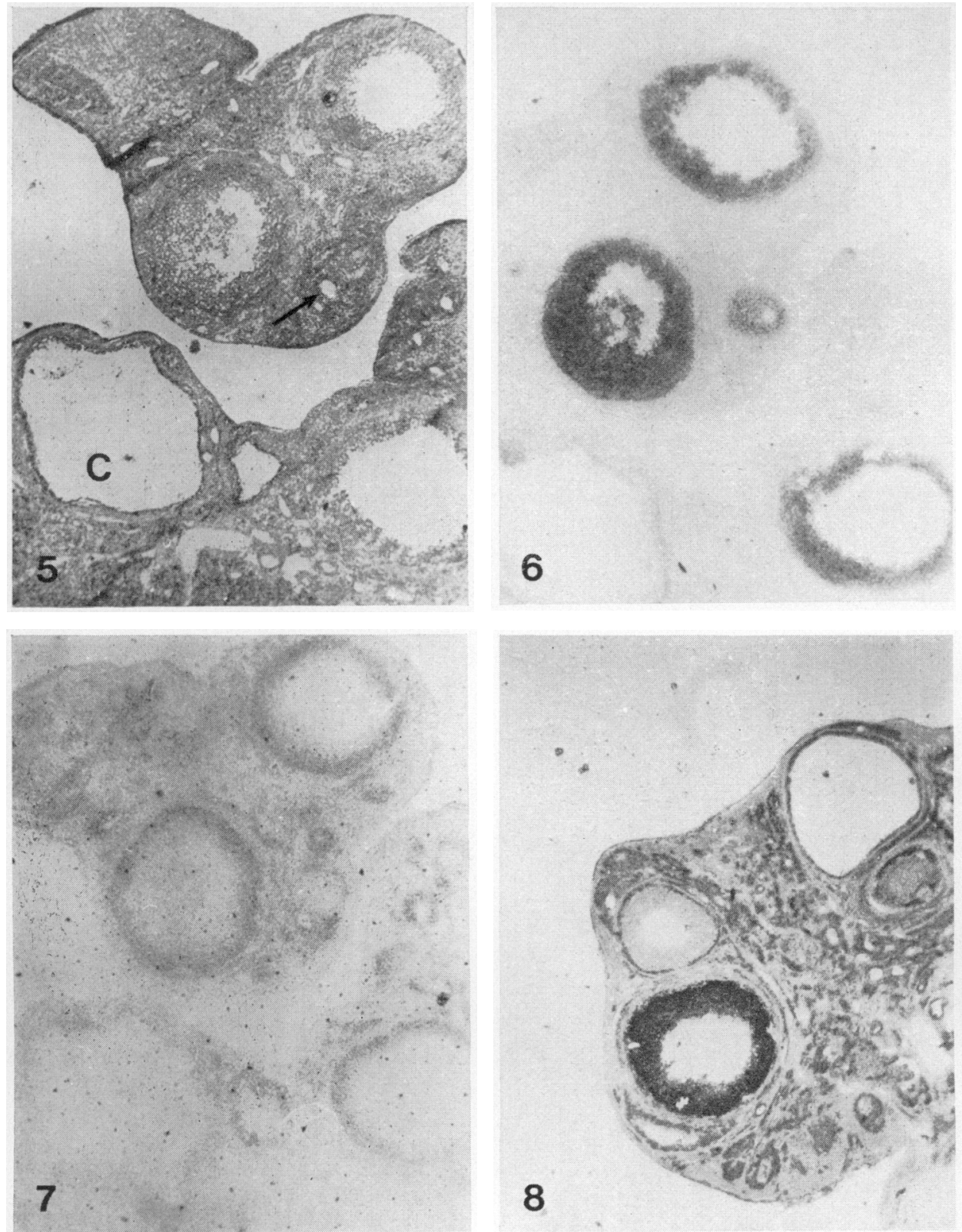

Figs 5,6 and 7. Adjacent sections from an ovary of an old constant-oestrous rat showing several normal and a cystic (C) follicle (Fig. 5). FSH (Fig. 6) and LH (Fig. 7) have bound to the medium-sized antral follicles but only lightly to the cystic follicle. Note the small follicle (arrow in Fig. 5) that binds FSH but not LH. Binding of $\mathrm{LH}$ by the interstitium is shown in Fig. $7 . \times 70$.

Fig. 8. Activity of $3 \beta$-hydroxysteroid dehydrogenase in an ovary from an old constant-oestrous rat. Activity is localized over the thecal and granulosa cells of intact follicles as well as over the theca of cystic follicles and over interstitial tissue and small follicles. $\times 70$. 
compensatory hypertrophy and hypersecretion of gonadotrophins after ovariectomy in female rats. Fert. Steril. 26, 271-276.

Huang, H.H. \& MeItes, J. (1975) Reproductive capacity of aging female rats. Neuroendocrinology 17, 289-295.

JONES, E.S. (1970) The ageing ovary and its influence on reproductive capacity. J. Reprod. Fert., Suppl. 12, 17-30.

LabHSETWAR, A.P. (1970) Ageing changes in pituitaryovarian relationships. J. Reprod. Fert., Suppl. 12, 99-117.

Leathem, J.H. \& MURONo, 'E.P. (1975) Ovarian $\triangle^{5}$-3 $\beta$-hydroxysteroid dehydrogenase in aging rats. Fert. Steril. 26, 996-1000.

MANDL, A.M. (1959) Corpora lutea in senile virgin laboratory rats. J. Endocr. 18, 438-443.
Peluso, J.J., Steger, R.W. \& Hafez, E.S.E. (1976) Development of gonadotrophin-binding sites in the immature rat ovary. J. Reprod. Fert. 47, 55-58.

Peng, M. \& Huang, H. (1972) Aging of hypothalamicpituitary-ovarian function in the rat. Fert. Steril. 23, 535-542.

Peppler, R.D. (1972) Effects of unilateral ovariectomy on follicular development and ovulation in cycling, aged rats. Am. J. Anat. 132, 423-428.

RYLE, M. (1972) The growth in vitro of mouse ovarian follicles of different sizes in response to purified gonadotrophins. J. Reprod. Fert. 30, 395-405.

ShaAR, C.J., Euker, J.S., RIEgle, G.D. \& Meites, J. (1975) Effects of castration and gonadal steroids on serum luteinizing hormone and prolactin in old and young rats. J. Endocr. 66, 45-51.

Received 15 March 1976 